\title{
Perilaku Kesalahan Puncak Spektrum Akibat Penggunaan Fungsi Jendela Kotak, Hanning, dan Flattop pada Sinyal Sinus Waktu Kontinu
}

\author{
Khuschandra dan Zainal Abidin \\ Laboratorium Dinamika PPAU-IR, Institut Tteknologi Bandung, Bandung \\ Email: khuschan_s23@yahoo.com dan za@dynamic.pauir.itb.ac.id
}

\begin{abstract}
ABSTRAK
Sinyal yang diperoleh dalam pengukuran getaran biasanya didominasi oleh sinyal sinusoidal. Dalam pengukuran getaran, sinyal direkam dengan menggunakan perangkat akuisisi data dengan waktu rekam yang terbatas. Akibatnya, terjadi pemotongan pada sinyal sinus sehingga menghasilkan kesalahan puncak spektrum. Kesalahan puncak spektrum dapat direduksi dengan menggunakan fungsi jendela. Sayangnya, penggunaan fungsi jendela, meskipun telah dikoreksi, masih menyebabkan kesalahan puncak spektrum. Dalam makalah ini dipaparkan penurunan persamaan matematik kesalahan puncak spektrum akibat penggunaan fungsi jendela Hanning dan flattop pada sinyal sinus. Sebagai pembanding, terlebih dahulu dipaparkan penurunan persamaan matematik kesalahan puncak spektrum akibat penggunaan fungsi jendela kotak pada sinyal sinus. Sebagai indikasi bahwa persamaan yang diturunkan sudah benar, maka persamaan matematik yang diperoleh divalidasi secara numerik dengan bantuan perangkat lunak Matlab.
\end{abstract}

Kata kunci: Kesalahan puncak spektrum, kesalahan, fungsi jendela, hanning, flattop, amplitudo.

\begin{abstract}
Vibration signals obtained from measurement are usually dominated by sinusoidal component. During measurement, the signal is recorded by a data logger with finite time record. This process causes truncation of the sinusoidal signal which may result a significant error of the spectral peak. This error is commonly reduced by the use of window functions. Unfortunately, the use of window function may cause spectral peak error although the obtained spectrum has been corrected. This paper describes derivation of mathematical equations of spectral peak error as a result of using Hanning and flattop windows on a sinusoidal signal. As a comparison, it initially describes derivation of mathematical equation of spectral peak error as a result of using uniform window on a sinusoidal signal. Finally, the equations which have been derived are validated using numerical simulation performed by Matlab software.
\end{abstract}

Keywords: Spectral peak error, error, window, hanning, flattop, amplitude.

\section{PENDAHULUAN}

Dalam pengukuran getaran, sinyal yang diperoleh biasanya menyerupai sinyal sinusoidal. Sinyal ini direkam dengan menggunakan perangkat akuisisi data. Pada kenyataannya, perangkat akuisisi data yang digunakan memiliki kemampuan yang terbatas sehingga lama waktu rekam yang digunakan pun terbatas. Hal ini mengakibatkan terjadinya pemotongan pada sinyal sinus yang terekam. Oleh karena itu, puncak spektrum yang diperoleh pun memiliki kesalahan. Kesalahan puncak spektrum ini dapat direduksi dengan menggunakan fungsi jendela. Akan tetapi, penggunaan fungsi jendela ini, meskipun telah dikoreksi, masih menyebabkan kesalahan pada puncak spectrum yang diperoleh.

Ahn [1] telah melakukan studi mengenai kesalahan akibat kebocoran pada spektrum suatu sinyal akustik. Kesalahan ini mengakibatkan pergeseran fasa, frekuensi, dan puncak spektrum yang diperoleh. Alhasil, nilai frekuensi, fasa, dan puncak spektrum yang sebenarnya dapat didekati berdasarkan data yang terkontaminasi oleh kesalahan tersebut. Selain itu, Burgess [2] memperkenalkan metode untuk memperkirakan nilai puncak spektrum dan frekuensi yang sebenarnya akibat penggunaan fungsi jendela kotak dan Hanning pada sinyal harmonik. Dalam makalahnya, Burgess [2] memperkirakan nilai yang sebenarnya 
dengan memperhatikan dua buah puncak yang saling berdekatan. Di samping itu, Breitenbach [3] memperkenalkan dua metode untuk megurangi kesalahan akibat kebocoran spektrum dari sinyal harmonik, yaitu metode ekstraksi perioda dan metode perhitungan spektrum hibrid.

Berdasarkan studi literatur diatas, analisis kesalahan puncak spektrum akibat penggunaan fungsi jendela Hanning dan flattop belum pernah dilakukan. Dalam makalah ini dipaparkan penurunan persamaan matematik kesalahan puncak spektrum akibat penggunaan fungsi jendela Hanning dan flattop pada sinyal sinus. Sebagai pembanding, terlebih dahulu dipaparkan penurunan persamaan matematik kesalahan puncak spektrum akibat penggunaan fungsi jendela kotak pada sinyal sinus. Dalam penurunan ini, pengaruh anti-aliasing filter dan derau (noise) tidak diperhitungkan dalam analisis. Sebagai indikator bahwa persamaan yang diturunkan sudah benar, maka persamaan matematik yang diperoleh divalidasi secara numerik dengan bantuan perangkat lunak Matlab.

\section{METODE PENELITIAN}

Metodologi penelitian yang digunakan ditampilkan pada Gambar 1. Tampak pada Gambar 1 bahwa penelitian ini diawali dengan mengidentifikasi masalah yang terjadi, yaitu adanya kesalahan puncak spektrum akibat penggunaan fungsi jendela kotak, Hanning, dan flattop pada sinyal sinus. Berikutnya, dilanjutkan dengan mempelajari literatur dan makalah yang terkait yang mendukung penelitian ini.

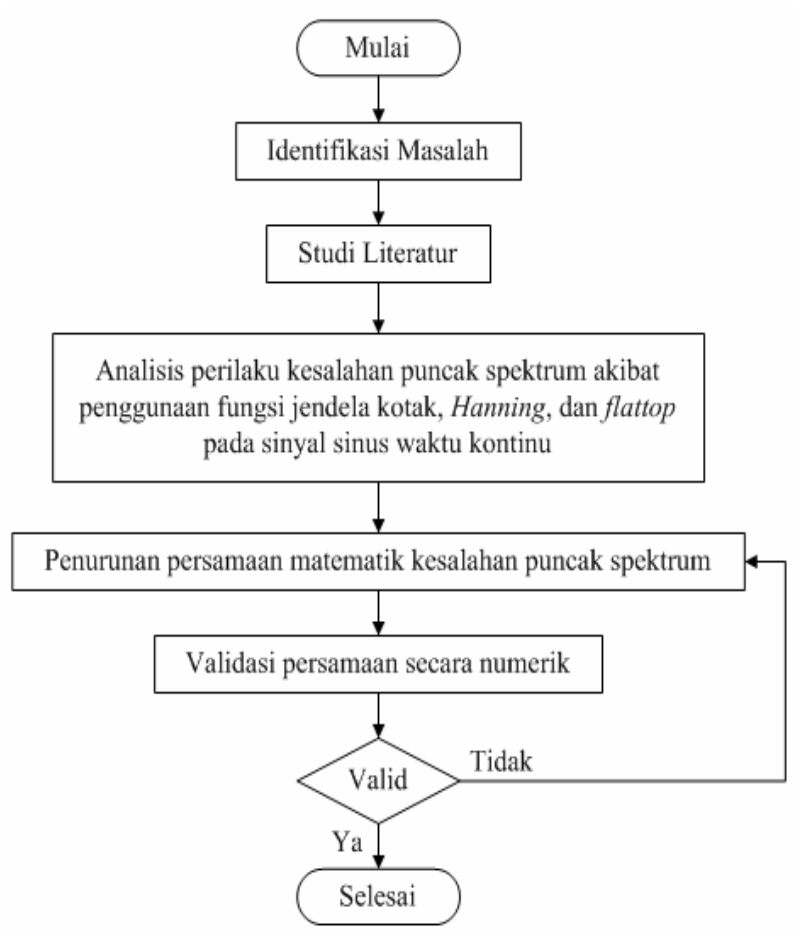

Gambar 1. Diagram Alir Penelitian
Langkah selanjutnya adalah analisis perilaku kesalahan puncak spektrum akibat penggunaan fungsi jendela kotak, Hanning, dan flattop pada sinyal sinus waktu kontinu. Analisis tersebut menghasilkan persaman matematik kesalahan puncak spektrum. Berdasarkan persamaan matematik yang diperoleh diungkapkan perilaku kesalahan puncak spektrum yang dimaksud. Sementara itu, sebagai indikator bahwa persamaan yang diturunkan sudah benar, maka perlu dilakukan validasi terhadap persamaan tersebut. Validasi ini dilakukan secara numerik dengan bantuan perangkat lunak MATLAB.

\section{HASIL DAN PEMBAHASAN}

\section{Penggunaan Fungsi Jendela Kotak, Hanning, dan flattop Pada Sinyal Sinus [4]}

Sinyal sinus dalam domain waktu kontinu dinyatakan dalam persamaan berikut:

$\mathrm{y}(\mathrm{t})=\mathrm{A} \sin (\omega \mathrm{t}+\phi) ;-\infty<\mathrm{t}<\infty$,

dimana $\mathrm{y}(\mathrm{t})$ adalah sinyal sinus waktu kontinu, A adalah amplitudo sinyal sinus, $\phi$ adalah fasa, $\omega=$ $2 \pi / \mathrm{T}_{\mathrm{s}}$, dan $\mathrm{T}_{\mathrm{s}}$ adalah perioda sinyal sinus. Apabila perekaman yang dilakukan dimodelkan dengan fungsi jendela kotak dan kemudian fungsi jendela tersebut digunakan pada sinyal sinus dalam Persamaan (1), maka diperoleh sinyal baru yang dinyatakan dalam persamaan berikut

$\mathrm{yu}(\mathrm{t})= \begin{cases}\mathrm{A} \sin (\omega \mathrm{t}+\phi) ; 0 \leq \mathrm{t}<\mathrm{T}_{\mathrm{r}} \\ 0 & ; \mathrm{t}<0, \mathrm{t} \geq \mathrm{T}_{\mathrm{r}}\end{cases}$

dimana $y_{u}(t)$ adalah sinyal sinus setelah melewati fungsi jendela kotak dan $\mathrm{T}_{\mathrm{r}}$ adalah waktu rekam. Seperti halnya fungsi jendela kotak, apabila digunakan fungsi jendela Hanning dan flattop pada sinyal sinus dalam Persamaan (1), maka diperoleh

$\mathrm{y}_{\mathrm{H}}(\mathrm{t})= \begin{cases}\mathrm{y}_{\mathrm{H} 1} ; 0 \leq \mathrm{t}<\mathrm{T}_{\mathrm{r}} \\ 0 \quad ; \mathrm{t}<0, \mathrm{t} \geq \mathrm{T}_{\mathrm{r}}\end{cases}$

dan

$\mathrm{y}_{\mathrm{F}}(\mathrm{t})=\left\{\begin{array}{l}\mathrm{y}_{\mathrm{F} 1} ; 0 \leq \mathrm{t}<\mathrm{T}_{\mathrm{r}} \\ 0 \quad ; \mathrm{t}<0, \mathrm{t} \geq \mathrm{T}_{\mathrm{r}}\end{array}\right.$

dimana

$\mathrm{y}_{\mathrm{H} 1}=\mathrm{A} \sin (\omega \mathrm{t}+\phi) \mathrm{w}_{\mathrm{H}}(\mathrm{t})$,

$\mathrm{y}_{\mathrm{F} 1}=\mathrm{A} \sin (\omega \mathrm{t}+\phi) \mathrm{w}_{\mathrm{F}}(\mathrm{t})$,

$\mathrm{w}_{\mathrm{H}}(\mathrm{t})=1-\cos \left(\frac{2 \pi t}{T_{r}}\right)$,

$$
\begin{aligned}
& 1-1,933 \cos \left(\frac{2 \pi t}{T_{r}}\right) \\
& +2,286 \cos \left(\frac{4 \pi t}{T_{r}}\right) \\
\mathrm{wH}(\mathrm{t})= & -0,388 \cos \left(\frac{6 \pi t}{T_{r}}\right) \\
& +0,032 \cos \left(\frac{8 \pi t}{T_{r}}\right)
\end{aligned}
$$


$\mathrm{y}_{\mathrm{H}}(\mathrm{t})$ adalah sinyal sinus setelah melewati fungsi jendela Hanning, dan $\mathrm{y}_{\mathrm{F}}(\mathrm{t})$ adalah sinyal sinus setelah melewati fungsi jendela flattop.

Puncak Spektrum Sinyal Sinus yang Telah Melewati Fungsi Jendela Kotak, Hanning, dan flattop [4]

Agar puncak spektrum dari masing-masing sinyal $\mathrm{y}_{\mathrm{U}}(\mathrm{t}), \mathrm{y}_{\mathrm{H}}(\mathrm{t})$ dan $\mathrm{y}_{\mathrm{F}}(\mathrm{t})$ dapat ditentukan, maka terlebih dahulu perlu ditentukan spektrum dari sinyal tersebut. Spektrum ini diperoleh dengan cara memanfaatkan koefisien deret Fourier. Setelah itu, ditentukan magnitude dari spektrum yang diperoleh. Berdasarkan magnitude spektrum tersebut kemudian ditentukan tinggi puncak spektrum berdasarkan nilai maksimum yang terjadi. Puncak spektrum dari sinyal sinyal $\mathrm{y}_{\mathrm{U}}(\mathrm{t}), \mathrm{y}_{\mathrm{H}}(\mathrm{t})$ dan $\mathrm{y}_{\mathrm{F}}(\mathrm{t})$ selanjutnya masing-masing dinotasikan dengan $\left|b_{\text {Un }}\right|_{\text {max }},\left|b_{\text {Hn }}\right|_{\text {max }}$, dan $\left|b_{\text {Fn }}\right|_{\text {max }}$, Puncak spektrum yang diperoleh dipaparkan pada penelitian Khuschandra [4].

\section{Kesalahan Puncak Spektrum Akibat Pengguna- an Fungsi Jendela Kotak, Hanning, dan Flattop [4]}

Kesalahan puncak spektrum dari sinyal $\mathrm{y}_{\mathrm{U}}(\mathrm{t})$, $\mathrm{y}_{\mathrm{H}}(\mathrm{t})$, dan $\mathrm{y}_{\mathrm{F}}(\mathrm{t})$, didefinisikan sebagai selisih antara puncak spektrum dari masing-masing sinyal $\mathrm{y}_{\mathrm{U}}(\mathrm{t})$, $\mathrm{y}_{\mathrm{H}}(\mathrm{t})$, dan $\mathrm{y}_{\mathrm{F}}(\mathrm{t})$ dan puncak spektrum teoritik dari sinyal sinus, dibagi dengan puncak spektrum teoritik dari sinyal sinus. Secara matematik, kesalahan puncak spektrum dari masing-masing sinyal tersebut dinyatakan dalam bentuk persamaan berikut

$\begin{aligned} \mathrm{E}_{\mathrm{rU}} & =\frac{\left|\mathrm{b}_{\mathrm{Un}}\right|_{\max }-\mathrm{A}}{\mathrm{A}}, \\ \mathrm{E}_{\mathrm{rH}} & =\frac{\left|\mathrm{b}_{\mathrm{Hn}}\right|_{\max }-\mathrm{A}}{\mathrm{A}},\end{aligned}$

dan

$\mathrm{E}_{\mathrm{rF}}=\frac{\left|\mathrm{b}_{\mathrm{Hn}}\right|_{\max }-\mathrm{A}}{\mathrm{A}}$,

Apabila masing-masing puncak spektrum yang dimaksud disubstitusikan ke dalam persamaan (9), (10), dan (11), maka diperoleh

$\mathrm{E}_{\mathrm{rU}}= \begin{cases}\mathrm{RI}_{\mathrm{Um}}\left(\mathrm{RI}_{\mathrm{Ub}}\right)^{1 / 2}-1 & \forall \mathrm{r}_{\mathrm{n}} \neq \mathrm{n}_{\mathrm{Um}} \\ 0 & \forall \mathrm{r}_{\mathrm{n}}=\mathrm{n}_{\mathrm{Um}} ;\end{cases}$
$\mathrm{E}_{\mathrm{rH}}=\left\{\begin{array}{lll}2\left(\mathrm{RI}_{\mathrm{H}}\right)^{1 / 2}-1 & \forall \mathrm{r}_{\mathrm{n}} \neq \mathrm{n}_{\mathrm{Hm}} \\ 0 & \forall \mathrm{r}_{\mathrm{n}}=\mathrm{n}_{\mathrm{Ym}}\end{array}\right.$

dan

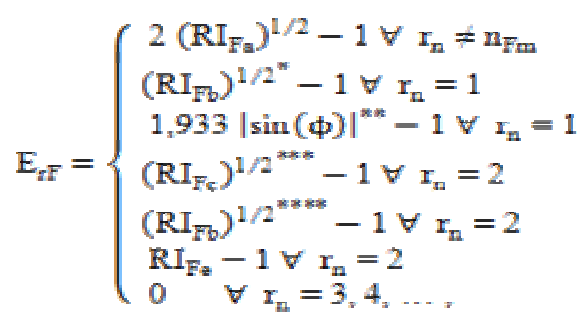

dimana

$\mathrm{RI}_{\mathrm{Ua}}=\frac{2\left|\sin \left(\pi r_{n}\right)\right|}{\pi \mid r_{n}{ }^{2}-n_{U m^{2}}}$

$\mathrm{RI}_{\mathrm{Ub}}=\mathrm{n}_{\mathrm{Um}}{ }^{2}+\left(\mathrm{r}_{\mathrm{n}}{ }^{2}-\mathrm{n}_{\mathrm{Um}}{ }^{2}\right) \mathrm{RI}_{\mathrm{Uc}}$

$\mathrm{RI}_{\mathrm{Uc}}=\sin ^{2}\left(\pi r_{\mathrm{n}}+\phi\right)$,

$\mathrm{RI}_{\mathrm{H}}=\operatorname{Re}_{\mathrm{HE}}{ }^{2}+\mathrm{Im}_{\mathrm{HE}}{ }^{2}$,

$\mathrm{RI}_{\mathrm{Fa}}=\mathrm{RE}_{\mathrm{FE}}{ }^{2}+\mathrm{Im}_{\mathrm{FE}}{ }^{2}$,

$\mathrm{RI}_{\mathrm{Fb}}=\left(\mathrm{k}_{1}\right)^{2} \sin ^{2}(\phi)+\left(\mathrm{k}_{2}\right)^{2} \cos ^{2}(\phi)$,

$\mathrm{RI}_{\mathrm{FE}}=\left(\mathrm{k}_{3}\right)^{2} \sin ^{2}(\phi)+\left(\mathrm{k}_{4}\right)^{2} \cos ^{2}(\phi)$,

$\mathrm{RI}_{\mathrm{Fe}}=1,286 \mid \sin (\mathrm{C} \mid * * * * *$

$\mathrm{k}_{1}=1,1605$,

$\mathrm{k}_{2}=0,7725$,

$\mathrm{k}_{3}=1,0160$,

$\mathrm{k}_{4}=0,9840$,

$\mathrm{r}_{\mathrm{n}}=\mathrm{T}_{\mathrm{r}} / \mathrm{T}_{\mathrm{s}}=\mathrm{k}+\mathrm{q}$,

$\mathrm{k}=$ bagian bilangan bulat dari $\mathrm{r}_{\mathrm{n}}$,

$q=$ bagian pecahan dari $r_{n}, 0 \leq q \leq 1$,

$\operatorname{Re}_{\mathrm{HE}}, \operatorname{Im}_{\mathrm{HE}}, \mathrm{Re}_{\mathrm{FE}}$, dan $\operatorname{Im}_{\mathrm{FE}}$ dipaparkan dalam penelitian Khuschandra [4],

Dalam persamaan diatas, $\mathrm{n}_{\mathrm{Um}}, \mathrm{n}_{\mathrm{Hm}}$, dan $\mathrm{n}_{\mathrm{Fm}}$ masingmasing merupakan nilai $\mathrm{n}$ yang menghasilkan $\mid$ bun $\mid$ max, $\left|b_{H n}\right|_{\max }$, dan $\mid$ bHn $\left.\right|_{\max }$, pada $r_{n}$ dan $\phi$ tertentu,

$\mathrm{n}=0,1,2, \ldots \ldots \ldots . . .$.

* berlaku untuk $0^{\circ} \leq 26^{\circ}$ atau $154^{\circ} \leq 206^{\circ}$ atau

$334^{\circ} \leq \phi \leq 360^{\circ}$,

$* *$ berlaku untuk $26^{\circ}<\phi<154^{\circ}$ atau $206^{\circ}<\phi<334^{\circ}$,

$* * *$ berlaku untuk $0^{\circ} \leq \phi \leq 46^{\circ}$ atau

$130,40^{\circ} \leq \phi \leq 229,60^{\circ}$ atau $314^{\circ} \leq \phi \leq 360^{\circ}$,

$* * * *$ berlaku untuk $46^{\circ} \leq \phi \leq 53,35^{\circ}$ atau

$123,05^{\circ} \leq \phi<130,40^{\circ}$ atau $229,60^{\circ}<\phi \leq 236,95^{\circ}$ atau

$306,65^{\circ} \leq \phi<314^{\circ}$,

$* * * * *$ berlaku untuk $53,35^{\circ}<\phi<123,05^{\circ}$ atau

$236,95^{\circ}<\phi<306,65^{\circ}$,

Berdasarkan Persamaan (12), (13), dan (14) dapat diungkapkan bahwa kesalahan puncak spektrum akibat penggunaan ketiga fungsi jendela tersebut tergantung pada $r_{n}$ dan $\phi$. Karena $r_{n}$ menyatakan rasio antara waktu rekam dan perioda sinyal sinus, maka dapat juga diungkapkan bahwa kesalahan puncak spektrum yang diperoleh juga tergantung pada lamanya waktu rekam yang digunakan, relatif terhadap perioda sinyal yang diukur.

Validasi Persamaan Kesalahan Puncak Spektrum Akibat Penggunaan Fungsi Jendela Kotak, Hanning, dan Flattop

Sebagai indikasi bahwa persamaan yang diturunkan sudah benar, maka perlu dilakukan validasi terhadap persamaan tersebut. Dalam hal 
ini, validasi dilakukan dengan cara membandingkan besar kesalahan puncak spektrum yang diperoleh dari Persamaan (12), (13), dan (14) dengan besar kesalahan puncak spektrum yang diperoleh dari simulasi dengan bantuan perangkat lunak Matlab. Simulasi ini dilakukan dengan cara menentukan suatu sinyal sinus yang memiliki amplitudo A dan perioda $\mathrm{T}_{\mathrm{s}}$ yang direkam dengan berbagai waktu rekam. Sinyal ini kemudian dilewatkan pada fungsi jendela kotak, Hanning, dan flattop. Pada simulasi ini digunakan waktu cuplik sebesar 0,001 detik supaya diperoleh kondisi yang mendekati waktu kontinu. Selanjutnya, agar kesalahan puncak spektrum dapat ditentukan, maka pada simulasi tersebut terlebih dahulu digunakan fungsi "FFT" pada Matlab untuk mendapatkan spektrum dari sinyal yang dimaksud. Setelah itu, ditentukan magnitude dari spektrum yang diperoleh. Berdasarkan magnitude spektrum ini kemudian ditentukan puncak spektrum berdasarkan nilai maksimum dari magnitude spektrum tersebut. Kesalahan puncak spektrum yang diperoleh dari simulasi ditentukan dengan cara mencari selisih antara puncak spektrum yang diperoleh dan puncak spektrum teoritik dari sinyal sinus, kemudian dibagi dengan puncak spektrum teoritik dari sinyal sinus. Di sini, validasi ini dilakukan pada $\phi=0^{\circ}$. Tujuannya adalah untuk memudahkan perbandingan antara kesalahan puncak spektrum yang diperoleh dari Persamaan (12), (13), dan (14) dan kesalahan puncak spektrum yang diperoleh dari simulasi pada grafik yang akan ditampilkan.

Perbandingan besar kesalahan puncak spektrum yang diperoleh dari Persamaan (12), (13), dan (14) dengan besar kesalahan puncak spektrum yang diperoleh dari simulasi masing-masing ditampilkan pada Gambar 2, 3, dan 4. Berdasarkan tiga gambar tersebut dapat disimpulkan bahwa adanya kesamaan nilai antara kesalahan puncak spektrum yang diperoleh dari Persamaan (12), (13), dan (14) dengan nilai kesalahan puncak spektrum yang diperoleh dari simulasi. Pada gambar-gambar tersebut terlihat bahwa kedua nilai tersebut saling berhimpit. Untuk lebih jelasnya, maka dipilih enam kasus dengan nilai $r_{n}$ bervariasi dari 4,23 sampai dengan 24,29. Nilai $r_{n}$ beserta nilai kesalahan puncak spektrum yang diperoleh dari Persamaan (12), (13), dan (14), serta nilai kesalahan puncak spektrum yang diperoleh dari simulasi masingmasing ditampilkan pada Tabel 1, 2, dan 3 . Berdasarkan Tabel 1 dapat disimpulkan bahwa nilai kesalahan puncak spektrum yang diperoleh dari Persamaan (12) dan nilai kesalahan puncak spektrum yang diperoleh dari simulasi memiliki nilai yang hampir sama. Sementara itu, berdasarkan Tabel 2 dan 3 dapat disimpulkan bahwa nilai kesalahan puncak spektrum yang diperoleh dari Persamaan (13), (14), dan nilai kesalahan puncak spektrum yang diperoleh dari simulasi memiliki nilai yang sama. Hal ini mengindikasi bahwa persamaan kesalahan puncak spektrum dari sinyal sinus kontinu yang telah melewati fungsi jendela kotak, Hanning, dan flattop yang telah diturunkan sudah benar.

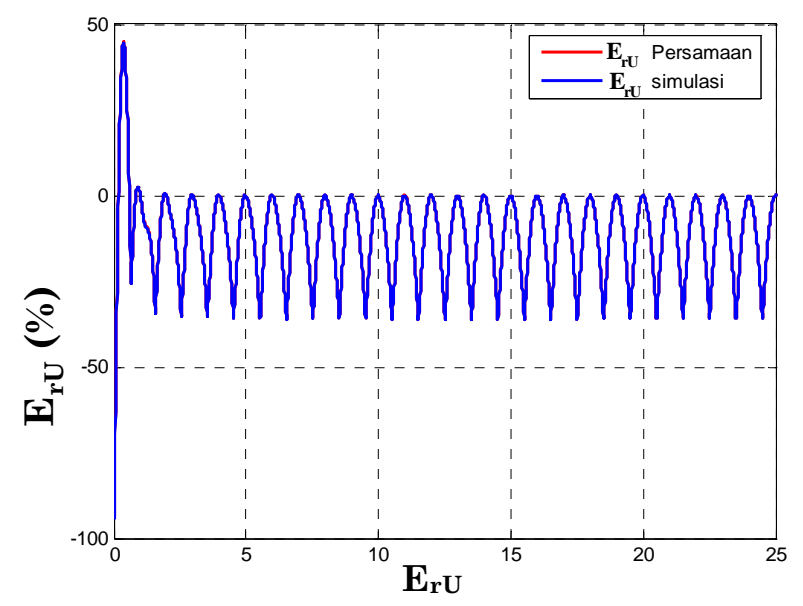

Gambar 2. Perbandingan Nilai Eru Persamaan (12) dan ErU Simulasi pada $\phi=0^{\circ}$.

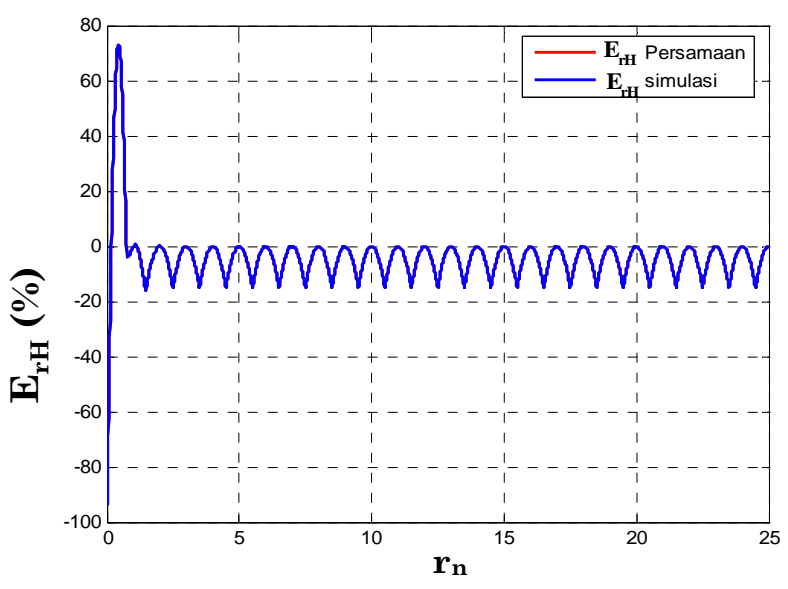

Gambar 3. Perbandingan Nilai ErH Persamaan (13) dan $\mathrm{E}_{\mathrm{rH}}$ Simulasi pada $\phi=0^{\circ}$.

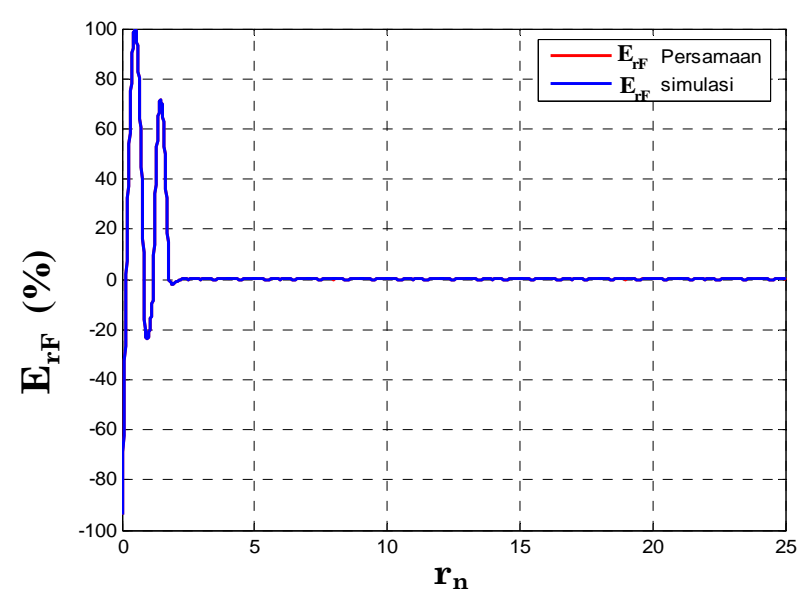

Gambar 4. Perbandingan Nilai ErF Persamaan (14) dan $\mathrm{E}_{\mathrm{rF}}$ Simulasi pada $\phi=0^{\circ}$. 
Tabel 1. Perbandingan Nilai Eru Persamaan dan

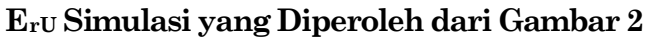

\begin{tabular}{crcr}
\hline Kasus & \multicolumn{1}{c}{$\mathrm{r}_{\mathrm{n}}$} & $\begin{array}{c}\text { ErU Pers. (10) } \\
(\%)\end{array}$ & $\begin{array}{c}\text { ErU Simulasi } \\
(\%)\end{array}$ \\
\hline 1 & 4,23 & $-8,763$ & $-8,779$ \\
2 & 8.51 & $-35,694$ & $-35,693$ \\
3 & 14,40 & 23.450 & $-23,460$ \\
4 & 18,50 & 35,470 & $-35,470$ \\
5 & 22,00 & 0,000 & 0,000 \\
6 & 24,29 & $-13,140$ & $-13,142$ \\
\hline
\end{tabular}

Tabel 2. Perbandingan Nilai $E_{\mathrm{rH}}$ Persamaan dan ErH Simulasi yang Diperoleh dari Gambar 3

\begin{tabular}{crrr}
\hline Kasus & \multicolumn{1}{c}{$\mathrm{r}_{\mathrm{n}}$} & $\begin{array}{c}\mathrm{E}_{\mathrm{rH}} \text { Pers. (11) } \\
(\%)\end{array}$ & $\begin{array}{c}\mathrm{E}_{\mathrm{rH}} \text { Simulasi } \\
(\%)\end{array}$ \\
\hline 1 & 4,23 & $-3,361$ & $-3,361$ \\
2 & 8.51 & $-14,550$ & $-14,550$ \\
3 & 14,40 & $-9,903$ & $-9,903$ \\
4 & 18,50 & $-15,120$ & $-15,120$ \\
5 & 22,00 & 0,000 & 0,000 \\
6 & 24,29 & $-5,307$ & $-5,307$ \\
\hline
\end{tabular}

Tabel 3. Perbandingan Nilai ErF Persamaan dan $\mathrm{E}_{\mathrm{rF}}$ Simulasi yang Diperoleh dari Gambar 4

\begin{tabular}{crcc}
\hline Kasus & $\mathrm{r}_{\mathrm{n}}$ & $\begin{array}{c}\text { ErF Pers. (12) } \\
(\%)\end{array}$ & $\begin{array}{c}\text { ErF Simulasi } \\
(\%)\end{array}$ \\
\hline 1 & 4,23 & $-0,027$ & $-0,027$ \\
2 & 8.51 & $-0,084$ & $-0,084$ \\
3 & 14,40 & $-0,002$ & $-0,002$ \\
4 & 18,50 & $-0,100$ & $-0,100$ \\
5 & 22,00 & 0,000 & 0,000 \\
6 & 24,29 & $-0,029$ & $-0,029$ \\
\hline
\end{tabular}

\section{Perilaku Kesalahan Puncak Spektrum Akibat Penggunaan Fungsi Jendela Kotak, Hanning, dan Flattop}

Berdasarkan Persamaan (12), (13), dan (14) dapat digambarkan perilaku kesalahan puncak spektrum untuk beberapa fasa sebagaimana ditampilkan pada Gambar 5, 6, dan 7. Gambar 5 menampilkan perilaku kesalahan puncak spektrum akibat penggunaan fungsi jendela kotak, Gambar 6 menampilkan perilaku kesalahan puncak spektrum akibat penggunaan fungsi jendela Hanning, dan Gambar 7 menampilkan perilaku kesalahan puncak spektrum akibat penggunaan fungsi jendela flattop.

Berdasarkan Gambar 5 dapat diungkapkan bahwa pada saat $r_{n}$ merupakan bilagan bulat $(q=0)$, yaitu pada saat waktu rekam yang digunakan merupakan kelipatan bilangan bulat dari perioda sinyal sinus, tidak terjadi kesalahan puncak spektrum, sedangkan pada saat $r_{n}$ bukan merupakan bilagan bulat $(0<q<1)$, akan terjadi kesalahan puncak spektrum. Di samping itu, pada $\mathrm{r}_{\mathrm{n}}<1$, diperoleh kesalahan puncak spektrum yang sangat signifikan. Hal ini disebabkan oleh waktu rekam yang digunakan sangat singkat. Oleh karena itu, pada saat yang sama, pengaruh fasa pada kesalahan puncak spektrum sangat signifikan, sehingga diperoleh nilai kesalahan yang bervariasi.
Namun, pada $r_{n}<1$, pengaruh fasa pada kesalahan puncak spektrum semakin berkurang seiring dengan semakin membesarnya harga $r_{n}$. Selain itu, kesalahan puncak spektrum yang diperoleh bersifat fluktuatif. Pada grafik terlihat bahwa saat pengaruh fasa pada kesalahan puncak spektrum sudah tidak signifikan lagi, diperoleh nilai kesalahan puncak spektrum dengan nilai maksimum sekitar -36,34\%. Nilai ini terjadi pada saat harga $q=0,5$.

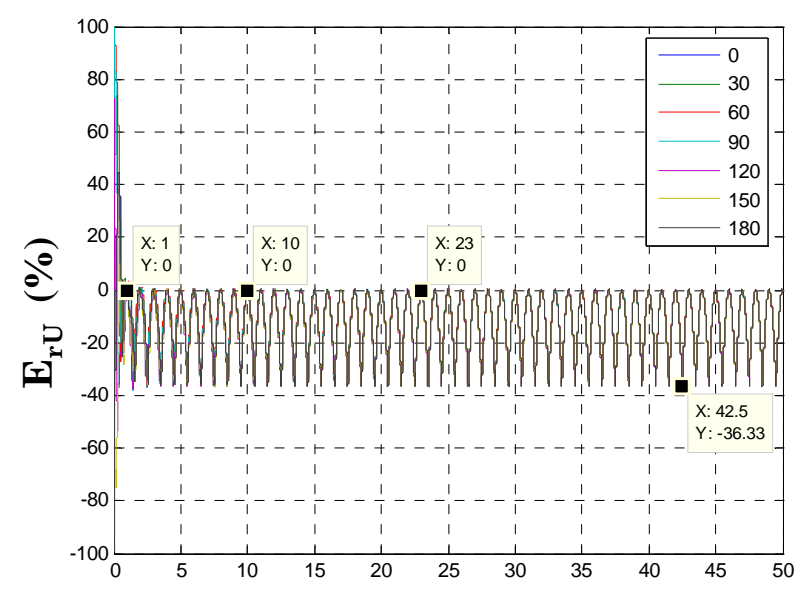

Gambar 5. Perilaku $E_{r U}$ terhadap $r_{n}, 0<r_{n}<50$

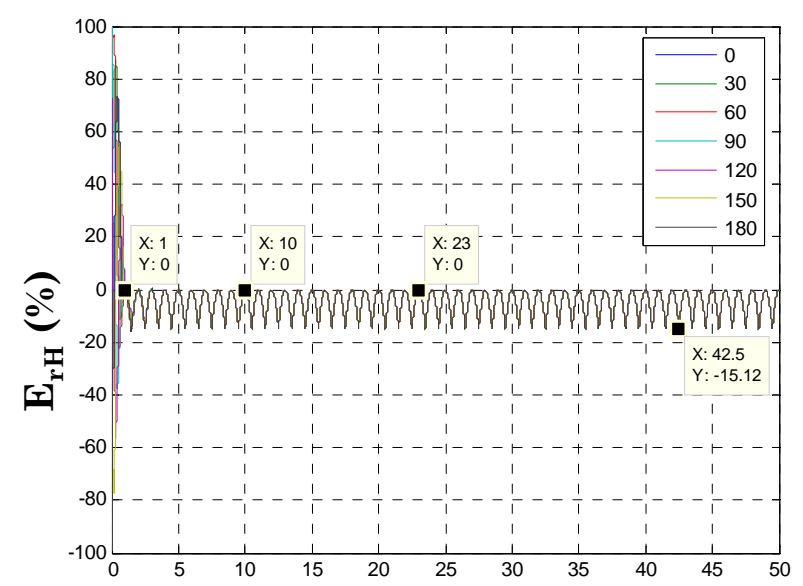

Gambar 6. Perilaku $E_{r H}$ terhadap $r_{n}, 0<r_{n}<50$

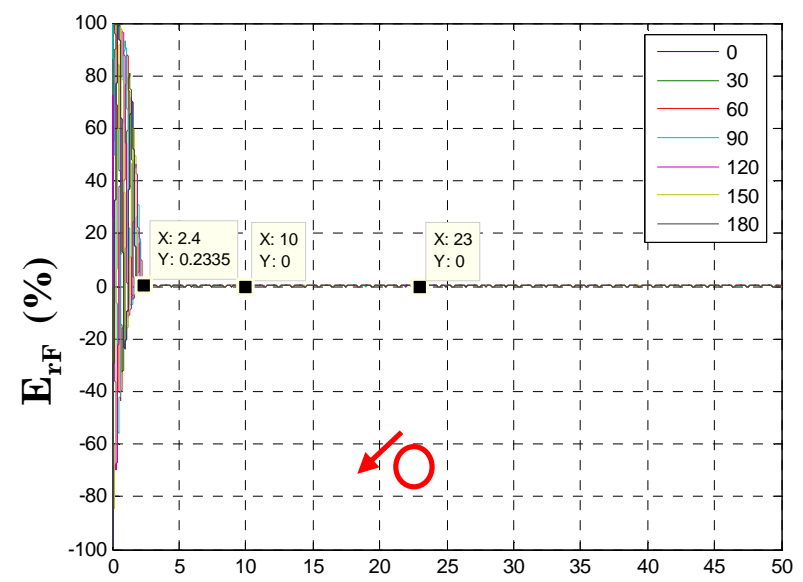

Gambar 7. Perilaku $E_{r F}$ terhadap $r_{n}, 0<r_{n}<50$ 
Berdasarkan Gambar 6 dapat diungkapkan bahwa pada saat $r_{n}$ merupakan bilagan bulat, tidak terjadi kesalahan puncak spektrum, sedangkan pada saat $r_{n}$ bukan merupakan bilagan bulat, akan terjadi kesalahan puncak spektrum. Di samping itu, pada $r_{n}<1$, diperoleh kesalahan puncak spektrum yang sangat signifikan. Hal ini disebabkan oleh waktu rekam yang digunakan sangat singkat. Oleh karena itu, pada saat yang sama, pengaruh fasa pada kesalahan puncak spektrum sangat signifikan, sehingga diperoleh nilai kesalahan yang bervariasi. Namun, pada $r_{n}<1$, pengaruh fasa pada kesalahan puncak spektrum semakin berkurang seiring dengan semakin membesarnya harga $r_{n}$. Selain itu, kesalahan puncak spektrum yang diperoleh bersifat fluktuatif. Kemudian, pada saat pengaruh fasa pada kesalahan puncak spektrum sudah tidak signifikan lagi, diperoleh nilai kesalahan puncak spektrum dengan nilai maksimum sekitar $-15,12 \%$. Nilai ini terjadi pada saat harga $q=0,5$.

Berdasarkan Gambar 7 dapat diungkapkan bahwa pada saat $r_{n}$ merupakan bilagan bulat, terjadi kesalahan puncak spektrum pada $r_{n}<1$ dan $\mathrm{r}_{\mathrm{n}}<2$, sedangkan pada $\mathrm{r}_{\mathrm{n}} \geq 3$, tidak akan terjadi kesalahan puncak spektrum. Sementara itu, pada saat $r_{n}$ bukan merupakan bilagan bulat, maka akan terjadi kesalahan puncak spektrum. Di samping itu, pada $r_{n}<2,4$, diperoleh kesalahan puncak spektrum yang sangat signifikan. Hal ini disebabkan oleh waktu rekam yang digunakan sangat singkat. Oleh karena itu, pada saat yang sama, pengaruh fasa pada kesalahan puncak spektrum sangat signifikan, sehingga diperoleh nilai kesalahan yang bervariasi. Namun, pada $r_{n}<2,4$, pengaruh fasa pada kesalahan puncak spektrum sudah tidak signifikan lagi. Selain itu, kesalahan puncak spektrum yang diperoleh bersifat fluktuatif. Selain itu, pada saat pengaruh fasa pada kesalahan puncak spektrum sudah tidak signifikan lagi, diperoleh nilai kesalahan puncak spektrum dengan nilai maksimum sekitar $-0,103 \%$. Nilai ini terjadi pada saat harga $q=0,5$.

\section{KESIMPULAN}

Berdasarkan hasil analisis dan pembahasan yang dilakukan dapat disimpulkan bahwa persamaan kesalahan puncak spektrum akibat penggunaan fungsi jendela kotak, Hanning, dan flattop pada sinyal sinus telah diturunkan dan telah divalidasi secara numerik. Kesalahan puncak spektrum yang diperoleh tergantung pada fasa (П), perioda sinyal sinus $\left(\mathrm{T}_{\mathrm{s}}\right)$ dan waktu rekam $\left(\mathrm{T}_{\mathrm{r}}\right)$ yang digunakan. Kurva kesalahan puncak spektrum yang diperoleh bersifat fluktuatif. Selain itu, kesalahan puncak spektrum tidak dapat direduksi dengan memperpanjang waktu rekam. Sementara itu, semakin panjang waktu rekam yang digunakan, pengaruh fasa pada kesalahan puncak spektrum semakin berkurang. Selanjutnya, pada saat pengaruh fasa sudah tidak signifikan lagi, diperoleh kesalahan puncak spektrum akibat penggunaan fungsi jendela kotak, Hanning, dan flattop dengan nilai maksimum masing-masing sebesar -36,34\%, - $15,12 \%$, dan $0,103 \%$. Di samping itu, pada saat pengaruh fasa masih signifikan, kesalahan puncak spektrum yang diperoleh dapat mencapai $100 \%$.

\section{DAFTAR PUSTAKA}

1. Ahn, S. J., et al., "A Study on the Leakage Error in the Spectrum of Acoustic Intensity", JSME Journal, Vol. 47, No. 1, 2004.

2. Burgess, J. C., "On Digital Spectrum Analysis of Periodic Signals", Journal of Acoustical Society of America, Vol. 58, No. 3, 1975.

3. Breitenbach, A., "Against Spectral Leakage", Elsevier, Measurement 25, 135-142, 1999.

4. Khuschandra, "Analisis Perilaku Kesalahan Puncak Spektrum Akibat Penggunaan Fungsi Jendela Kotak, Hanning, dan Flattop Pada Sinyal Sinus", Tesis Magister, Program Studi Teknik Mesin, ITB, 2010. 